\title{
THE ECOLOGY OF THE TAMAR ESTUARY IV. THE DISTRIBUTION OF THE FAUNA AND FLORA ON BUOYS
}

\author{
By A. Milne, M.A., B.Sc., Ph.D. \\ From the Plymouth Laboratory and Marischal College, \\ Aberdeen University
}

(Text-figs. I and 2)

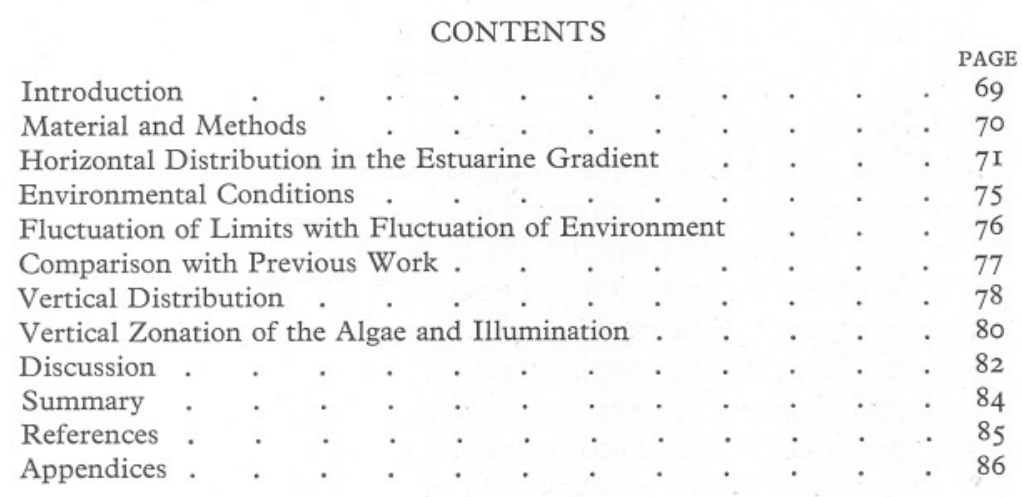

\section{INTRODUCTION}

In considering the fauna and flora of estuaries, particularly the question of penetration from the sea and zonation along the estuarine gradient, a study of the growth on floating buoys has a special significance. The buoys supply a habitat in which certain variables affecting the bottom fauna are eliminated. Not only is a substratum of a constant type provided, but because the buoys are floating the organisms attached to them are subjected to a constant degree of immersion, thus eliminating an important element in the fluctuation of the environment, due to the rise and fall of the tide, to which the fauna and flora of the shore is subjected. A series of buoys along an estuary, such as exists in Plymouth Sound and Hamoaze, virtually supplies an experimental series in which the only important environmental variables are salinity conditions and (to a much lesser degree) turbidity of the water.

According to Orton (1930), the black varnish coating of buoys provides more or less "innocuous surfaces". Buoys are primarily available only for sessile organisms such as barnacles, mussels, coelenterates, Bryozoa, ascidians and algae. But once the latter have settled, they collect among their crevices, byssi and holdfasts, quantities of silt and plant debris, and this in turn provides 
a foothold and food for amphipods, and to a lesser extent, worms. Animals such as Ligia, Orchestia and faera, which have no pelagic stage in their development, have slender chances of reaching the buoys in mid-river; while certain species, such as Littorina littorea, even though they have pelagic larvae, cannot withstand constant immersion (Flattely \& Walton, I922, p. 207). Colonization must be affected by the time at which the buoys are laid down (see Appendix I, p. 86), for this may happen when one species is breeding and it may have established itself before another, which breeds later, is able to gain a foothold. How far the present distribution is influenced by this fact it is difficult to say, but the possibility must not be overlooked. The longer a floating structure is in the water, the richer and more varied its fauna tends to be (cf. Orton, 1930; Fraser, 1938).

\section{Material AND Methods}

A series of buoys extending from open sea (Mewstone) to typical estuarine conditions (Neal Point) was chosen. Certain physical and chemical factors for this area have already been discussed (Cooper \& Milne, I938, I939; Milne, 1938). The buoys varied to some extent in size and shape, but all had some flat, vertical surfaces from which collections could be taken and zonation measured; their immersed portions varied from one to a little over two metres in depth. Buoys lie at their moorings from I2 to I5 months (see Appendix I) and then are towed gently to the wharf a little above Cremyll where they are scraped and repainted. Those mentioned here were examined immediately after they were raised from the water. There are other buoys closely neighbouring, or at the same level in the estuarine gradient as, each of the buoys named in Fig. I. With the exception of New Rock, Panther and H I buoys, one to three of these were examined in each case as a check.

The following buoys, not shown in the map in Part I, are situated in relation to buoy $\mathrm{D}_{4}$ as follows (approximately): Mallard, I km. west; New Rock, $3.2 \mathrm{~km}$. south-south-west; Panther, $3.3 \mathrm{~km}$. south; and Mewstone, $6.5 \mathrm{~km}$. south-south-east. The Mallard and D buoys lie inside the Sound; while the New Rock, Panther and Mewstone lie outside the Breakwater.

Collections were made separately from each of the three plant zones, and from three different points in each zone. The dimensions of the areas scraped were governed by the uniformity of the distribution in the zone and by the size of the zone. In Zone III, where most of the fauna is concentrated, three squares of $20 \mathrm{~cm}$. side were scraped. The macrofauna and macroflora only were studied; microfauna like copepods and Protozoa, and microflora like coating diatoms were omitted. 


\section{Horizontal Distribution In the Estuarine Gradient}

The horizontal distribution on the buoys is given in Fig. I. Neal Point is not necessarily the up-river limit of those organisms found on it, since no buoys were available for examination above this point. It seems reasonable to take the absence of species on Neal Point buoys which are present on $\mathrm{H}$ I 5 as indicating their limit at $\mathrm{H} \mathrm{I}_{5}$, even though there are no buoys above Neal Point, for the Hamoaze series ( $\mathrm{H}_{\mathrm{I}}-\mathrm{H} \mathrm{I}_{5}$ and Neal Point) was laid down and lifted about the same time.

The following have been omitted from Fig. I; of these $A-E$ are algae, the remainder animals:

\section{LIST I}

A. The filamentous green algae, unidentified, which are abundant on all the buoys in the series.

$B$. Fucoids, young stages, present on $\mathrm{H}$ I-H II.

C. Ascophyllum nodosum Le Jol, present on $\mathrm{H} 7$ and $\mathrm{H}$ II, and almost full grown on the former; strangely absent on the seaward buoys.

D. Hypoglossum woodwardii Kylin, found only on $\mathrm{H}$ II, rare.

E. Chylocladia sp., on $\mathrm{H} \mathrm{I}$, rare.

F. Anomia ephippium L., on Mallard buoy, rare.

G. Idotea granulosa Rathke, on Mallard and $\mathrm{H} 4$ buoys, rare.

$H$. Limnoria lignorum (Rathke), in wood baulks protecting the surface of $\mathrm{H} 7$, and tunnels only on H II, common.

I. Cellepora costazii Audouin, common on Mewstone and abundant on New Rock buoys.

F. Schizoporella hyalina (L.), on Panther buoy, present.

$K$ and L. Cirratulus cirratus (O. F. Muller) and Polyophthalmus pictus (Dujardin), on Panther buoy, present.

M. Ophiothrix fragilis (Abildgaard), on Mewstone, common but young, disk 3-5 $\mathrm{mm}$.

$N$ to $R$. Gonothyraea loveni Ellis \& Sollander, Opercularella lacerta (Johnston), Calycella sp., Campanulina repens Allman, Coryne vel Syncoryne sp., all present but rare on $\mathrm{H}_{7}$ and $\mathrm{H}$ I I buoys, possibly present on others-but method of collection inefficient (see Appendix II).

S. Tubularia larynx Ellis \& Sollander, similarly, but noticed in abundance on Panther and Mallard, and common on $\mathrm{H}_{4}$, while adult stalks were present on Neal Point buoy. Tubularia dies off in winter.

T. Thalassomyia frauenfeldii Zett and Clunio marinus Hal, insect larvae (see Fig. I), and possibly others, since investigation was not exhaustive.

In Fig. I the data for Mewstone buoy are also not included because there is a possibility that one or two species were missed, since the collection was made several hours after the buoy had been taken from the water. The species are listed below. Several of the marine species present on other open sea buoys are absent but Mewstone is more out of the zone affected by estuarine waters.

\section{LIST II. Mewstone Buoy}

Filamentous green algae, a.; Ulva linza var. lanceolata (Kutz), a.; U. lactuca var. latissima (D.C.), c.; Laminaria digitata Lamour, a.; L. saccharina Lamour, c.; Mytilus edulis L., c.; Fassa falcata (Montagu), a.; Stenothöe monoculoides (Montagu), c.; Balanus 


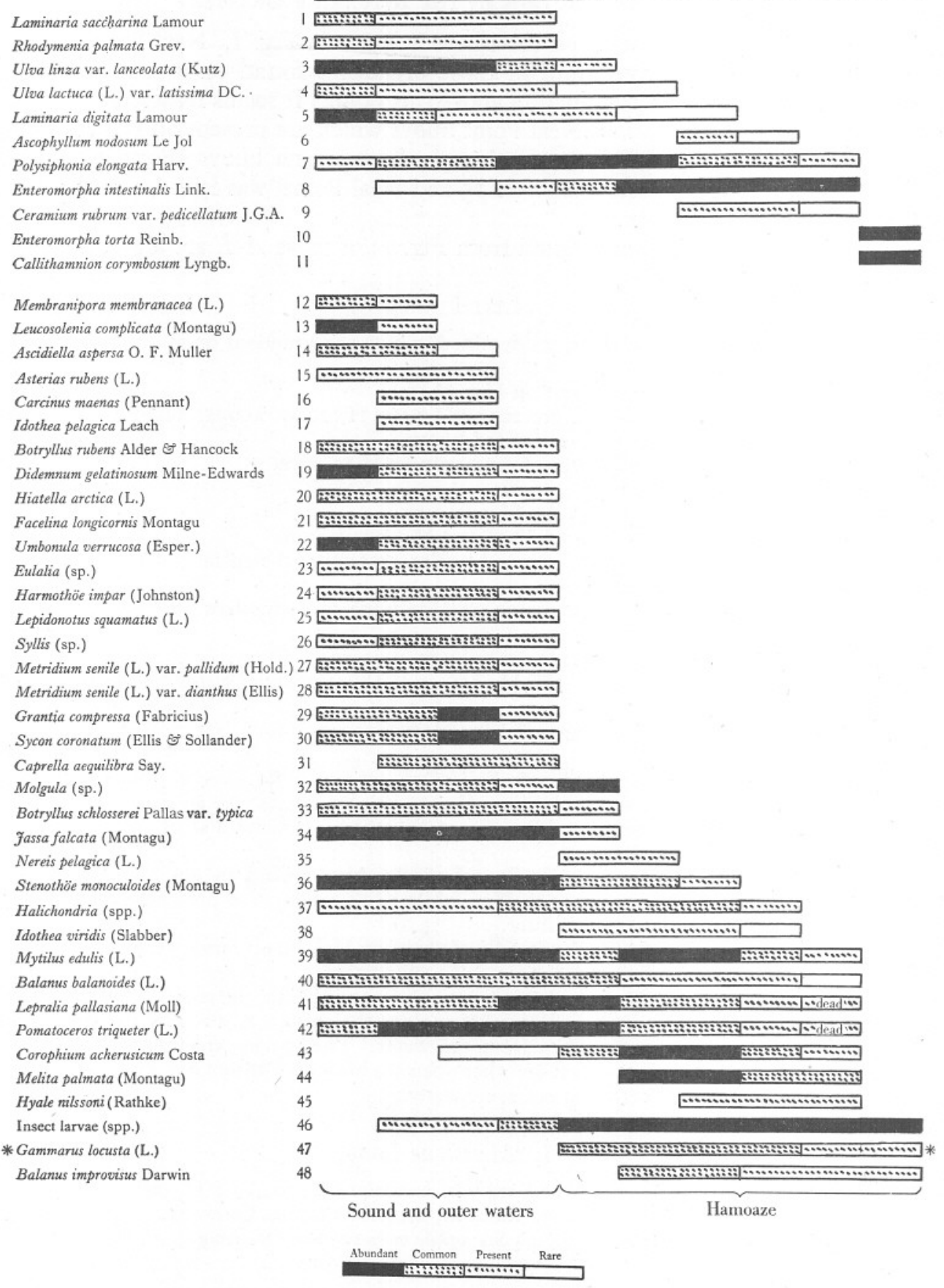

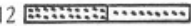

13 -...........

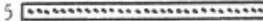

18

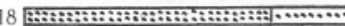

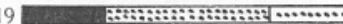

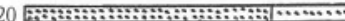

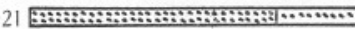

(1)

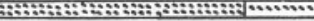

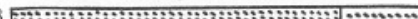

35

(1)

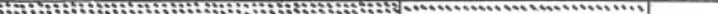

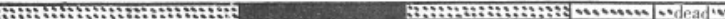

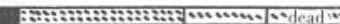

एकी

n.............................

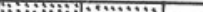

Fig. I. Quantitative horizontal distribution showing limits on buoys in the Tamar Estuary, Plymouth Sound and outside.

* Later found that at Neal Point buoy (only) this was a var. of Gammarus zaddachi Sexton. 
balanoides (L.), c.; Lepralia pallasiana (Moll), c.; Cellepora costazii Audouin, c.; Pomatoceros triqueter (L.), c.; Ophiothrix fragilis (Abildgaard), $p$.

(a. abundant; $c$. common; $p$. present.)

As in the Tees (Alexander, etc., I935) it was found "that the range of species even of the same phylum differed greatly". A considerable difference is also evident in the resistance, i.e. penetrative power of two species of the same genus (cf. Enteromorpha, Ulva, Laminaria, Idotea and Botryllus). Since the Hamoaze series, $\mathrm{H}$ I to $\mathrm{H}$ I5 and Neal Point, were all laid during NovemberDecember 1935 and examined during February-March I937, there were at least thirty species available for colonization of these buoys (see Fig. I). This is the total species on all the buoys of the Hamoaze series. But the number of species present on each buoy was as follows $(A, B, N-S$ in list I, and insect larvae are omitted.)

$\begin{array}{cccccc}\mathrm{H} \mathrm{I} & \mathrm{H}_{4} & \mathrm{H}_{7} & \mathrm{H} \mathrm{II}_{19} & \mathrm{H} \mathrm{I}_{5} & \text { Neal Point } \\ \text { I9 } & \mathrm{I}_{7} & \text { I9 } & \text { I8 } & \text { 10 } & 4\end{array}$

Moreover, there is not one species which is present on all the Hamoaze series, though five-Polysiphonia elongata, Enteromorpha intestinalis, Mytilus edulis, Balanus balanoides, Corophium acherusicum - are present on $\mathrm{H}$ I to $\mathrm{H}$ I5.

In the Tamar there is a great deal of suspended silt and this increases upriver. It is sometimes suggested that animals with delicate ciliary or pore mechanisms (suspension feeders) will be limited by suspended silt. The sponges, Coelenterata, Polyzoa and tunicates, together with Mytilus, Pomatoceros and Balanus may be classed as suspension feeders. The numbers of suspension and non-suspension feeders on each buoy in the series were as follows:

$\begin{array}{lcc}\quad \text { Buoy } & \text { Suspension feeder } & \begin{array}{c}\text { Non-suspension } \\ \text { feeder }\end{array} \\ \text { Panther } & \text { I9 } & \text { I4 } \\ \text { Mallard } & \text { I5 } & \text { I6 } \\ \text { D 4 } & \text { I4 } & \text { II } \\ \text { H I } & 7 & 7 \\ \text { H } 4 & 6 & 8 \\ \text { H 7 } & 6 & 8 \\ \text { H II } & 6 & 6 \\ \text { H I5 } & 3 & 5 \\ \text { Neal Point } & \text { I } & 2\end{array}$

Fig. I.

Buoys and their positions

In the map in Part I, it will be seen that the mouth of the estuary (zero position) is taken as being Devil's Point. The position of the buoys relative to this are as follows:

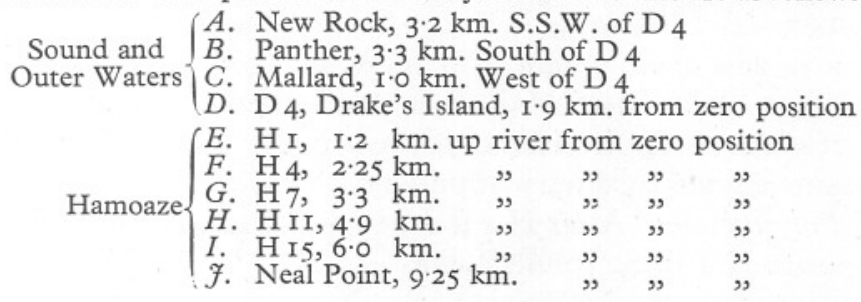


The five species of hydroid ( $N-R$, List I) on $\mathrm{H}_{7}$ and $\mathrm{H}_{\text {II }}$ buoys, and Tubularia larynx on $\mathrm{H}_{4}$, are omitted. Thus on the Tamar buoys, just as in the bottom fauna of the Tees, Tay and Tamar estuaries (Alexander, et al., I935) there is no marked difference between the penetration of the two groups.

Although the relative abundance as well as the range is shown in Fig. I, it must be clearly understood that too much stress must not be laid on the former since no detailed counts were made. The figure is only intended to indicate trends in density. In any case, the size-composition would be necessary to show the degree of ecological success. Generally the organisms become less numerous and smaller towards the lower end of their salinity range, as very obviously shown without measurement by Laminaria and Mytilus. Where there is a tendency to lesser density, not size, towards the seaward end of the range, e.g. in Polysiphonia, Halichondria, Lepralia, Pomatoceros and Corophium, this must be partly due to competition for space. Those organisms which do penetrate the estuary have some of the space normally shared with those which do not, since fewer species come in than drop out. Thus (excluding $A, B$ and $N-S$ in List I, and insect larvae) it is found that of the 39 species present on the Panther buoy, only 34 penetrate to the

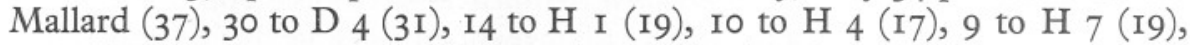
7 to $\mathrm{H} \mathrm{II}$ (I7), 4 to $\mathrm{H}_{\text {I5 }}$ (I0), and o to Neal Point (4). (The figures in brackets represent the total number of species present on the buoys with the exceptions noted above.) For example Polysiphonia elongata becomes denser at $\mathrm{D} 4$ where the other algae, Laminaria digitata and L. saccharina, accompanying it in Zone III are becoming scarce; Halichondria similarly at D.4, where Sycon compressum and Grantia compressa are beginning to fall away. Of course the competition is not necessarily within a phylum only. Numbers are also reduced when one species gives place to another with a certain amount of overlapping, especially where those species have similar habits: this occurs where Fassa falcata begins to give place to Corophium acherusicum at $\mathrm{H}$ I (both live in tubular galleries in silt); and to a lesser extent with the two species of barnacles. A very abrupt changeover with no overlapping is seen where, at $\mathrm{H}$ I5, Polysiphonia is completely replaced by Callithamnion in Zone III, and Enteromorpha intestinalis by E. torta in Zone II. Zonation, as pointed out by Elton (1927), is more clearly marked in plants than in animals.

The occurrence of Nereis pelagica at $\mathrm{H}$ I and $\mathrm{H}_{4}$ only, and not seawards of this, is explained by the fact that on these buoys a few had got a foothold in empty nailholes in the protecting wood baulks. But the presence of such truly marine organisms as Gammarus locusta, Ascophyllum nodosum and fucoids on Hamoaze buoys and their absence on more seaward buoys is not so easily explained. Fig. I shows that Molgula is common on all seaward buoys but tends to decrease towards the Hamoaze; just inside however, at $\mathrm{H}$ I buoy, it suddenly attains an extraordinary abundance, to a large extent crowding out Mytilus and Polysiphonia. After H I it drops out abruptly on buoys, though it is found opposite $\mathrm{H}_{4}$ in St John's Lake. 
The following are the dominant forms grouped roughly in order of their importance:

In the Sound and Outer Waters:

(i) Mytilus, Fassa, Ulva, Polysiphonia, filamentous green algae.

(ii) Laminaria, worms and Bryozoa, Tubularia.

In the Hamoaze and up to Neal Point:

(i) Mytilus, Corophium, Enteromorpha, Polysiphonia (replaced, as noted above, by Callithamnion at Neal Point).

(ii) Lepralia, Pomatoceros, Gammarus.

Speaking generally for the whole series, the dominant forms are filamentous green algae, Ulva, Enteromorpha, Polysiphonia, Mytilus and amphipods. The mussel competes with the algae, chiefly Polysiphonia, with which it shares Zone III.

\section{ENVIRONMENTAL CoNDITIONS}

Salinity, temperature and hydrogen-ion concentration are discussed more fully in Part III of this series (Milne, I938). Current and wave action are similar on the $\mathrm{H} \mathrm{I}-\mathrm{H}$ I5 series of buoys; a little more wave action might be expected at those buoys between Devil's Point and the Mallard, though the current is much the same; Panther, New Rock and Mewstone buoys are subject to the violence of the open sea. The current in the Hamoaze

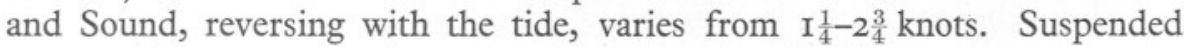
matter, always present in greater quantity than in the sea, increases upriver and during winter or spate conditions (Cooper \& Milne, 1938). The sides of the buoys are perpendicular so that silt will not easily be deposited. There are no industrial effluents in the Tamar and only a relatively small amount of crude sewage. The hydrogen-ion concentration seldom falls as low as $p \mathrm{H}_{7} .5$ even at $\mathrm{H}$ 15. Diurnal fluctuation of the temperature of the water passing the buoys is small but the seasonal range increases up-riverat Saltash the extremes may be $2-4^{\circ} \mathrm{C}$. higher or lower than those at the Breakwater. Organisms on the buoys are subject to constant immersion, and this, as noted before, excludes certain species. This condition, however, avoids desiccation and large fluctuations in temperature, but lays the organisms open to more protracted and greater salinity fluctuation than on an equivalent point on the shore. Various workers have shown that certain marine organisms can be accustomed to salinities steadily decreasing to that of freshwater, provided the process is sufficiently gradual. Rate as well as range of salinity fluctuation is therefore important. Part III shows how this varies from high to low water, daily, fortnightly and seasonally from the exceptionally rainy winter of $1936-7$ to the rather dry summer of 1937 , so that most contingencies are covered. There is a progressive increase in the range of fluctuation in an up-river direction. Differences such as $12.8 \%$ ( $9 \mathrm{~atm}$. of osmotic pressure) at Saltash, and 5.5 and $5.2 \%(3.5 \mathrm{~atm}$.) at Drake's Island and the Breakwater respectively may have to be withstood in $6 \mathrm{hr}$. (tide) at springs in winter; 
while summer conditions are more stable, the corresponding figures being $\mathrm{I} .8 \%(\mathrm{I} .5 \mathrm{~atm}$.) and 0.2 and $0.3 \%$. Maximum ranges within one tidal cycle were $33 \cdot 7-7 \cdot 6 \%$ at Saltash, $33 \cdot 7-19 \cdot 5 \%$ at Drake's Island, and $34 \cdot 9-26 \cdot 6 \%$ at the Breakwater.

Fischer-Piette (I93I et seq.) has shown that salinity is by far the most important agency controlling estuarine distribution. He demonstrated that horizontal limits fluctuate according to rainfall (i.e. lowering of salinity) summer and winter and from year to year.

With the aid of Fig. I in the present paper and Table II in Part III, and the map in Part I, some idea of the resistance of certain species to salinity fluctuation may be formed.

\section{Fluctuation of Limits with Fluctuation of Environment}

There was an exceptionally high rainfall and therefore a correspondingly low salinity in the winter of $1936-7$. Towards the end of this rainy period skeletons of Pomatoceros and Lepralia were present at $\mathrm{H} \mathrm{I5}$, while living specimens were found on H II ; similarly, Limnoria tunnels were found to be occupied at $\mathrm{H} 7$ but empty at $\mathrm{H}$ II. This withdrawal of limits is undoubtedly due to a steepening of the estuarine gradient at this time (Fischer-Piette, I93I). Crawford (1937, p. 65I) in the years immediately preceding states "in 267 specimens counted at random from Neal Point Buoys there was found

$\begin{array}{lrll}\text { Corophium acherusicum } & 259 & \text { Gammarus zaddachi } & 2 \\ \text { C. insidiosum } & 3 & \text { Melita palmata } & \text { I } \\ \text { fassa falcata } & 2 & & \end{array}$

Idotea viridis and Hyale were also present." Of these, only Gammarus zaddachi was present when the buoys were examined in March 1937.

But this rainy winter did not cause the retreat of all organisms. Percival's (I929) lists of intertidal organisms were made during and after a dry summer, ${ }^{\star}$ while after the wet winter (1936-7) the writer noted the intertidal penetration of seven of his species:

\begin{tabular}{lrr}
\multicolumn{1}{c}{ Species } & \multicolumn{2}{c}{ Penetration in kilometres } \\
\cline { 2 - 3 } Molgula sp. & $\mathrm{I} 928$ & $\mathrm{I} 937$ \\
Mytilus edulis & $2 \cdot 0$ & $2 \cdot 0$ \\
Littorina littorea & $\mathrm{r} 3.3$ & $\mathrm{I} \cdot 3 \cdot 3$ \\
L. rudis & $9 \cdot 4$ & $9 \cdot 4$ \\
Balanus balanoides & $9 \cdot 4$ & $9 \cdot 4$ \\
Halichondria spp. & $\mathrm{I} 3.3$ & $\mathrm{II} \cdot 0$ \\
Littorina obtusata & 9.4 & $5 \cdot 0$ \\
& 9.4 & $\mathrm{II} \cdot 0$
\end{tabular}

Four species had maintained their position, two had retreated and one had actually advanced. With the exception of one retreating species, Halichondria,

* Percival does not mention the rainfall of the preceding winter. 
and one static species, Molgula, the remainder are all able to close up and possibly escape harm while awaiting the return of suitable conditions (see later).

\section{COMParison With Previous Work}

Orton's (I930) list of the chief organisms growing on or in experimental material-floating rafts, and piles fixed at L.W.S.T.-in Cawsand Bay and Plymouth Sound differ from the present findings chiefly because some of the material was not subject to constant immersion, and most of his rafts were in the sea three times as long as the Admiralty buoys.

Percival's (1929) distribution of intertidal and bottom species in the Tamar are compared in Table I. There are differences both in numerical order of and extent of penetration. If salinity alone were the limiting factor then at least the numerical order of penetration would be the same. The distribution

\section{Table I. Comparison of Extent of Penetration of Species Common to the Studies of Percival (I929) and the Present Paper}

Distances given in kilometres up-estuary $(+)$ or down-estuary $(-)$ from zero position at Devils' Point (see map in Part I).

(Gammarus locusta is omitted because Percival did not recognize G. zaddachi as a separate species.)

$\begin{array}{lc}\begin{array}{l}\text { Intertidal and Bottom } \\ \text { I928 }\end{array} & \mathrm{km} . \\ \text { Carcinus maenas } & +2 \mathrm{I} \cdot 7 \\ \text { Ascidiella aspersa } & +\mathrm{I} 4 \cdot 0 \\ \text { Botryllus schlosserei } & +\mathrm{I} 3 \cdot 6 \\ \text { Pomatoceros triqueter } & +\mathrm{I} 3 \cdot 6 \\ \text { Melita palmata } & +\mathrm{I} 3 \cdot 3 \\ \text { Balanus balanoides } & +\mathrm{I} 3 \cdot 3 \\ \text { Lepralia pallasiana } & +\mathrm{I} 1 \cdot 0 \\ \text { Fassa falcata } & +9 \cdot 4 \\ \text { Ophiothrix fragilis } & +9.4 \\ \text { Harmothöe impar } & +9 \cdot 4 \\ \text { Metridium senile } & +7 \cdot 7 \\ \text { Cirratulus cirratus } & +5.4\end{array}$

\begin{tabular}{lc}
\multicolumn{1}{c}{ Buoys } & $\mathrm{km}$. \\
I937 & $+6 \cdot 0$ \\
Balanus balanoides & $+6 \cdot 0$ \\
Melita palmata & $+5 \cdot 0$ \\
Lepralia pallasiana & $+5 \cdot 0$ \\
Pomatoceros triqueter & $+\mathrm{I} \cdot 0$ \\
Botryllus schlosserei & $+\mathrm{I} \cdot 0$ \\
Fassa falcata & $-2 \cdot 0$ \\
Harmothöe impar & $-2 \cdot 0$ \\
Metridium senile & $-3 \cdot 0$ \\
Ascidiella aspersa & $-3 \cdot 0$ \\
Carcinus maenas & $-5 \cdot 3$ \\
Cirratulus cirratus & $-7 \cdot 5$ \\
Ophiothrix fragilis &
\end{tabular}

on buoys ought to be the best indicator of order of penetration, or resistance to the salinity gradient, of those animals able to live on buoys: for while the substratum of the shore is irregular in many ways, thus bringing other factors into play, that on the buoys is constant in texture and slope. Organisms on the shore generally penetrate farther than those on buoys (Table I). This is believed to be due chiefly to the greater and more protracted salinity fluctuation on the buoys than on a corresponding point on the intertidal area or bottom. Mussels were absent on the Neal Point buoys in spring 1937, while the richest bed in the Plymouth district lies directly beneath them on the bottom.

The effect of rainfall conditions on extent of penetration is discussed in the preceding section.

Fraser (1938) investigated the fauna of buoys submerged for one year in the Mersey Estuary in a salinity gradient varying from sea conditions down to 
$27.4 \%$. This resembles salinity conditions in the Sound and Outer Waters at Plymouth. The fauna in the Mersey is poorer in number of species than the Tamar; sponges, polyzoa and Carcinus maenas are absent in the former. Throughout the range in the Mersey estuary, Mytilus edulis, Harmothöe imbricata, Lepidonotus squamatus, Nereis pelagica, Podocerus variegatus and Asterias rubens are common; Metridium senile and hydroids, Balanus crenatus, and ascidians are less common; B. balanoides is practically absent. Fassa falcata is common at the seaward end of the range (cf. Tamar). The density of Asterias and Nereis here contrasts with their paucity in the Tamar. Apart from geographical position, the pollution and possibly the silt suspension factors, the former of which is much greater in the Mersey, may largely account for the differences.

The various comparisons made illustrate the difficulty of attributing the limiting factor to salinity alone.

\section{VERTICAL DISTRIBUTION}

The flora of the buoys showed a particularly clean-cut vertical zonation. The dimensions of the various belts are given in Table II; the data are averages from 2 to 4 buoys (except for Panther where only one buoy was examined) and three measurements were made on each buoy.

\section{Table II. Width of the Algal Zones on the Buoys in Centimetres}

Zone III was limited by the depth of the buoy.

$\begin{array}{lccc}\text { Buoy } & \text { Zone I } & \text { Zone II } & \text { Zone III } \\ \text { Panther } & 0-17 \cdot 8 & \text { I7.8-35.6 } & 35 \cdot 6-127 \cdot 0 \\ \text { Mallard } & 0-18 \cdot 6 & 18 \cdot 6-35 \cdot 6 & 35 \cdot 6-218 \cdot 5 \\ \text { D 4 } & 0-17 \cdot 8 & 17 \cdot 8-35 \cdot 6 & 35 \cdot 6-111 \cdot 8 \\ \text { H } 4 & 0-10 \cdot 2 & 10 \cdot 2-25 \cdot 4 & 25 \cdot 4-127 \cdot 0 \\ \text { H } 7 & 0-9 \cdot 7 & 9 \cdot 7-22 \cdot 3 & 22 \cdot 3-246 \cdot 6 \\ \text { H II } & 0-8 \cdot 0 & 8 \cdot 0-18 \cdot 0 & 18 \cdot 0-183 \cdot 1\end{array}$

Uppermost was a narrow belt of filamentous green algae unidentified. This belt, termed Zone I, was present on all the buoys.

Just below was a slightly wider belt, Zone II, occupied by Ulva or Enteromorpha, or both. Ulva (2 spp.) was present from Mewstone to $\mathrm{H}_{4}$ and Enteromorpha from Panther to Neal Point. E. intestinalis was completely replaced by E. torta at Neal Point buoys, while the two species of Ulva are present together for some part of their horizontal range, though $U$. lactuca finally outstrips $U$. linza in penetration of the estuary.

Below this again was a very much wider belt, Zone III, where Polysiphonia elongata was dominant. Polysiphonia was absent at Mewstone, present from New Rock to $\mathrm{H} \mathrm{15}$, and completely replaced by Callithamnion corymbosum at Neal Point. A few brown algae-chiefly Laminaria spp., and other red algaesuch as Rhodymenia and Ceramium, were present also in Zone III. Moreover, 
on the seaward buoys, some fronds of Ulva lactuca tended to spread downwards a few centimetres and mingle with Polysiphonia, but the latter was by far the dominant.

Thus Zones I and II were occupied solely by green algae, while Zone III was occupied predominantly by red, and to a lesser extent by brown.

Both the size and density of fronds tended to increase a little downwards in each zone. Zone II was more luxuriant than Zone I, and Zone III than Zone II.

No macrofauna was present in Zone I; in Zone II a few species were present, especially Stenothöe, insect larvae, and occasionally Idotea; but the greater part of the fauna, including the species in Zone II, was confined to Zone III. The macrofauna increased in abundance with depth below the surface, reached its maximum at about $50 \mathrm{~cm}$., and maintained that abundance to the bottom of the buoy.

Colman (I933, p. 454) and Orton (I929, p. 278) give the upper limits of certain algae in normal habitats in the Plymouth district. Below, these limits are compared with those on the buoys by giving the least distance in metres below E.H.W.S.T. at which they grow on the littoral; and regarding the surface mark on the buoys as E.H.W.S.T. Unfortunately, in their works only three species could be found which occur on the buoys but they are examples from the green, upper brown, and lower brown algal zones normal to the shore.

\begin{tabular}{|c|c|c|c|}
\hline Species & $\begin{array}{l}\text { Shore } \\
\text { (Colman) }\end{array}$ & $\begin{array}{l}\text { Shore } \\
\text { (Orton) }\end{array}$ & Buoys \\
\hline $\begin{array}{l}\text { Enteromorpha sp. } \\
\text { Ascophyllum nodosum } \\
\text { Laminaria digitata }\end{array}$ & $\begin{array}{l}\mathrm{I} \cdot 6 \mathrm{I} \\
4 \cdot 55\end{array}$ & $\begin{array}{l}0.34 \\
1.56 \\
5.22^{\star}\end{array}$ & $\begin{array}{r}<0.08 \\
0.18\end{array}$ \\
\hline Laminaria digitata & 4.55 & $5 \cdot 22^{\star}$ & 0.22 \\
\hline
\end{tabular}

According to Newton (I93I) Polysiphonia elongata, Ceramium rubrum, Callithamnion corymbosum and Rhodymenia palmata live in rock pools between tidemarks as well as below low water mark which is the usual habitat of "red" algae; but Hamel (1923) gives $-25 \mathrm{~m}$. Chart Datum as the depth at which Rhodymenia palmata has been found growing at St Malo. Nevertheless the table above shows that there is an extraordinary compression of zonation on the buoys.

This compression of the normal littoral algal zonation must be due chiefly to light conditions on the buoys and to a lesser extent to constant immersion. Since buoys float, waves have practically no uncovering action. Algae are influenced by emersion just as animals are (Fischer, I928; Baker, I9I0; and others). Brown algae such as Ascophyllum and fucoids, being intertidal, are at a disadvantage owing to constant immersion, while most of the reds, and to a lesser extent some of the browns such as the species of Laminaria, are naturally constantly immersed in their normal habitat. Ascophyllum and fucoids only appear on buoys in the Hamoaze to which the laminarians do not penetrate. Where other conditions are suitable, then, the laminarians must oust the other 
algae which are not so fitted to withstand the constant immersion of Zone III. The compression of the zonation even in the open sea at Mewstone buoy emphasizes the importance of tidal action in controlling zonation on the shore.

\section{Vertical Zonation of the Algae and Illumination}

Børgesen (1908) states that sublittoral algae raise their vertical limit in caves where illumination is poorer than on the shore. In the estuary light penetration is much less than in the open sea (Cooper \& Milne, 1938). On proceeding from the sea inwards, not only does the total amount of light penetrating become progressively less but its composition changes with depth. "In marked contrast to the open sea, red light penetrates as well or better than green, and blue is cut down most rapidly" (p. 526).

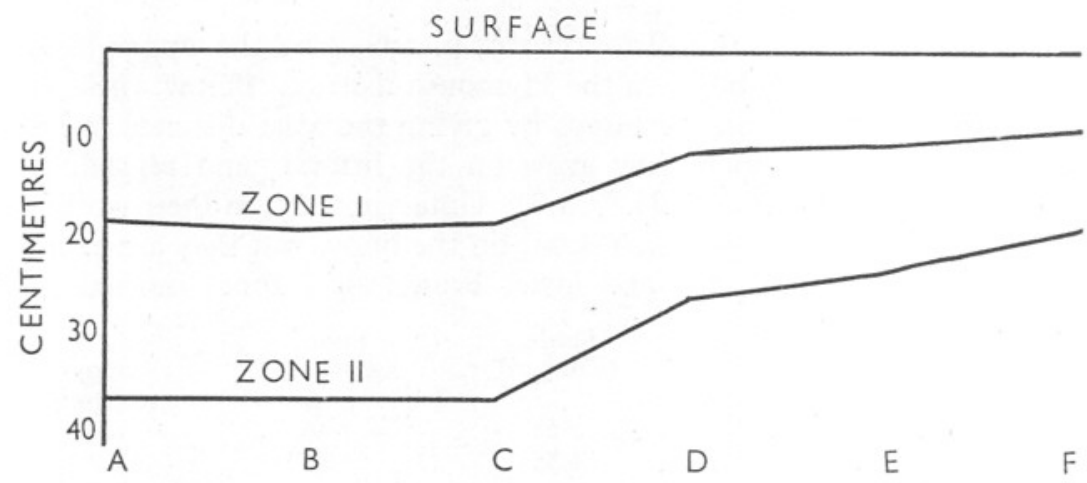

Fig. 2. Lower limits of upper algal zones on buoys. $A$, Panther; $B$, Mallard; $C$, Drake's Island $\mathrm{D}_{4} ; D, \mathrm{H}_{4}$, Hamoaze; $E, \mathrm{H}_{7}$, Hamoaze; $F, \mathrm{H}_{\mathrm{I}}$, Hamoaze.

On the Mewstone buoy, where conditions are more or less those of the open sea, there is the typical triple zonation mentioned above, but Zone III contains no red algae, Laminaria only being present. The lesser penetration of light in the Sound possibly favours the (red) Polysiphonia and Rhodymenia so that in this situation they establish themselves and tend to oust Laminaria in Zone III. Light conditions are more or less uniform in the Sound but penetration decreases abruptly on entering the Hamoaze and continues to decrease up-river (at least to Neal Point buoy). The algal zonation follows the light conditions closely, for the bottom limits of Zones I and II are fairly constant in the Sound but rise abruptly on entering the Hamoaze and rise steadily on proceeding up the Hamoaze (Fig. 2 and Table II).

Daylight factors ${ }^{\star}$ at the zonal boundaries found by the author on the buoys in Plymouth Sound and on Hamoaze No. 7 buoy were presented in our earlier papers (Cooper and Milne, 1938, 1939). They suggested forcibly that the

* From here to the end of this section I am indebted to Dr L. H. N. Cooper for assistance. 
depths of the boundaries are very largely conditioned by the daylight factors. Although we have zonal data for two other Hamoaze buoys, Nos. 4 and II, we have light records only at Nos. I, 7 and I5. Approximate extinction coefficients. have been calculated for the water near buoys Nos. 4 and II on the assumption that the extinction coefficient for a given wave band varies linearly with the distance between two buoys, not too far apart. Thus

$$
\mu_{\lambda(\mathrm{H} 4)}=\frac{\mu_{\lambda(\mathrm{H} 1)}+\mu_{\lambda(\mathrm{H} 7)}}{2}
$$

and

$$
\mu_{\lambda(\mathrm{H} 11)}=\mu_{\lambda(\mathrm{H} 7)}+\frac{\mathrm{I} \cdot 5}{2 \cdot 6}\left[\mu_{\lambda(\mathrm{H} 15)}-\mu_{\lambda(\mathrm{H} 7)}\right] .
$$

Using such values for the extinction coefficients, the daylight factor at each buoy and on each occasion, $F$, has been calculated from the equation

$$
F=\operatorname{IOO}\left(\frac{I_{\lambda_{1}} e^{-\mu_{\lambda_{1}} d}+I_{\lambda_{2}} e^{-\mu_{\lambda_{2}} d}+\ldots+I_{\lambda_{9}} e^{-\mu_{\lambda_{9}} d}}{I_{\lambda_{1}}+I_{\lambda_{2}}+\ldots+I_{\lambda_{9}}}\right),
$$

where $I_{\lambda_{1}}$, etc., represent the spectral energy of a given wave-band in air, and $I_{\lambda_{1}}+I_{\lambda_{2}}+\ldots+I_{\lambda_{9}}=\mathrm{I}$.

Since in 1937 the medium red filter, S 66, was not available, the rather large gap between the S6I and S 72 filters has had to be closed by taking the mean values of the extinction coefficients as measured for those two filters ( $\mu_{M}$; see Cooper \& Milne, 1938, p. 510) and adding 0.6 as an approximate distilled water correction factor at $660 \mathrm{~m} \mu\left(\mu_{D W}\right)$. The daylight factors so obtained are presented in Table III together with those from Plymouth Sound and Hamoaze No. 7 buoy. Both light transmission and zonation in Plymouth Sound were sufficiently uniform for us to amalmagate our results into one

\begin{tabular}{|c|c|c|c|c|c|}
\hline & \multirow{2}{*}{$\begin{array}{l}\text { Plymouth } \\
\text { Sound }\end{array}$} & \multicolumn{3}{|c|}{ Hamoaze } & \multirow{2}{*}{$\begin{array}{l}\text { Weighted } \\
\text { mean }\end{array}$} \\
\hline & & $\mathrm{H}_{4}$ & $\mathrm{H}_{7}$ & $\mathrm{H}$ II & \\
\hline \multicolumn{6}{|c|}{ Boundary of Zones I and II } \\
\hline Depth in metres & $\ldots \quad 0.180$ & 0.102 & 0.097 & 0.080 & \\
\hline June I7 (high water) & $78 \cdot 3$ & $82 \cdot 5$ & 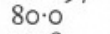 & $84 \cdot 4$ & 80 \\
\hline June 23 (low water) & & $79 \cdot 4$ & $77 \cdot 8$ & $76 \cdot 9$ & 77 \\
\hline February I8 (high water) & 65.4 & $71 \cdot 4$ & $69 \cdot 8$ & $73 \cdot 4$ & 70 \\
\hline \multicolumn{6}{|c|}{ Boundary of Zones II and III } \\
\hline Depth in metres & $\ldots \quad 0.356$ & 0.254 & 0.223 & 0.180 & \\
\hline June I7 (high water) & & & & $72 \cdot 9$ & 64 \\
\hline June 23 (low water) & $59 \cdot 2$ & $56 \cdot 7$ & $56 \cdot 5$ & $55 \cdot 2$ & 57 \\
\hline February I8 (high water) & $43 \cdot 7$ & $45^{\circ} 0$ & $45^{\circ} 0$ & $50 \cdot 1$ & 45 \\
\hline \multicolumn{6}{|c|}{$\begin{array}{l}\text { Bottom of buoy (within Zone III) } \\
\text { (Mallard) }\end{array}$} \\
\hline Depth in metres & $\ldots \quad 2.19$ & $I \cdot 27$ & $2 \cdot 47$ & $I \cdot 83$ & . \\
\hline June I7 (high water) & $7 \cdot 4$ & Ir.O & 0.97 & $3 \cdot 1$ & . \\
\hline $\begin{array}{l}\text { June } 23 \text { (low water) } \\
\text { February I } 8 \text { (high water) }\end{array}$ & $5 \cdot 5$ & $6 \cdot 8$ & 0.35 & 0.29 & .. \\
\hline February I8 (high water) & 0.85 & 2.I & 0.020 & 0.15 & .. \\
\hline
\end{tabular}
group, in itself evidence for our thesis.

Table III. Daylight Factors at Zonal Boundaries on Buoys (I937) 
On June I7 I937, the estuary was optically almost uniform from Hamoaze No. 7 buoy as far up indeed as Neal Point buoy, a condition no doubt somewhat rare and accounting for the high daylight factors calculated for Hamoaze No. I I buoy on that date. The rest of the additional data serves but to confirm our view that the zonation of algae on buoys in Hamoaze and Plymouth Sound is mainly, if not entirely, governed by the daylight factors.

The factors for the very turbid estuary at low water on February I6 I937, have not been calculated. Conditions must have been so adverse for photosynthesis that even quite considerable fluctuations in absolute light intensity may be safely ignored.

We may summarize the range of daylight factors found within the three zones, excepting times of winter spate, thus:

Zone I

Zone II

Zone III

$$
\begin{gathered}
\underset{\%}{\operatorname{Daylight} \text { factor }} \\
70-100 \\
45-80 \\
>\quad \mathrm{I}-64
\end{gathered}
$$

\section{Discussion}

In an ecological study one is always confronted by the doubt that the environment has not been correctly assessed by merely choosing (of necessity) what are thought to be the most important factors. The relative importance of environmental factors ought therefore to be discussed.

The sea (tide) brings plankton and nutrient salts* while the river brings detritus and possibly nutrient salts also. Thus detritus and plankton feeding animals apparently find no lack of their foods in the estuary, but for plants the opacity of the water must soon limit photosynthesis. Considering the relative bulks of sewage and water in the estuary basin together with the speedy rate of renewal of the latter by tide and river, sewage here is probably innocuous since it will be quickly diluted and swept away. Thus the Tamar has a relatively clean estuary and oxygen concentration probably never falls so low that it could be a significant factor alone. Sponges and Polyzoa are absent on Mersey buoys, and though present on seaward buoys are not generally exuberant in the Tamar. The latter estuary, though well oxygenated, contains a high silt content, and the Mersey, besides being polluted, seems to have a higher one still. The dominance of mussels in both estuaries may thus be explained, for, as Fischer-Piette notes (1935, p. I55), "the mud which accumulates between their shells and among their byssus threads soon eliminates animals which require clean water, like many sponges, Bryozoa, Hydrozoa, and compound ascidians".

* Generally speaking: "So far as nutrient salts are concerned conditions in Plymouth Sound are usually better than those of the open sea at the same season" (Dr L. H. N. Cooper). 
Huntsman (I9I8) has shown that a combination of comparatively high temperature and low salinity influenced the vertical distribution of certain marine species, so that the temperature gradient in the Tamar may be more important than some factors. But undoubtedly salinity is the chief limiting agency, outweighing all others (see Fischer-Piette I93I). Yet all the other factors even though they may be thought harmless * of themselves (because of their usually small range of variation and their apparently negligible difference from sea conditions) must help both singly and collectively to make salinity a greater or lesser limiting factor. It is well known that one physical or chemical factor may affect the action of another. This point is emphasized by a comparison of intertidal penetration of marine species in several estuaries of similar salinity gradient (Tees, Tay, Tamar and La Rance in France): there are broad similarities, but there are also striking differences both in extent of penetration and in the order in which the organisms drop out. These differences or at least the latter difference would be absent if salinity were the only limiting factor. Fischer-Piette's (I93I) "salinity" is really rainfall which includes $p \mathrm{H}$, temperature, current and suspended matter changes. In nature, then, one can only speak of a chief limiting factor. In a clean estuary the chief one is salinity.

Mytilus certainly (unpublished work) and Balanus, Pomatoceros and Lepralia possibly, can close up and wait for the return of suitable salinity conditions; but that amphipods, coelenterates and algae in the Tamar can withstand osmotic changes up to $9 \mathrm{~atm}$. four times in $24 \mathrm{hr}$. and often for several days at a time without their tissues disrupting is remarkable. Atkins (I9I6, p. I79) has shown that Ascophyllum nodosum in seawater of osmotic pressure $22.6 \mathrm{had}$ an osmotic pressure of $23.6 \mathrm{~atm}$. after $24 \mathrm{hr}$. in the dark in the laboratory; on being placed in diluted sea water (I0.7 atm.) the same thallus, after $3 \frac{1}{2}$ hr., was at $13.4 \mathrm{~atm}$. Thus "alteration of the medium. . .leads to a very rapid readjustment of pressure through the diffusion outwards of salts". Atkins goes on to say that "injurious effects.... are occasioned by fluctuations which are too rapid for the proper adjustment to be effected". Although the changes at Saltash ( $\mathrm{H}_{\text {I5 }}$ ) are large at certain times, they are never so abrupt as this (being spread gradually over $6 \mathrm{hr}$.) and never so large (9 atm. as opposed to I2).

The horizontal distribution of algae in the different zones may be partly affected by the spectral composition (as well as the daylight factor) of the penetrating light since this changes in the up-river direction. But probably the horizontal gradients in salinity and temperature have some influence as well as light in this connexion. While the zonal boundary curves of flora on buoys are undoubtedly a function of the light factor, it may be that these other factors also influence the absolute limit of vertical distribution for it is conceivable that salinity and temperature may affect the metabolism of the plant cell and thus its capacity for photosynthesis. Some of the invertebrate * (Cf. Fischer-Piette, I93I.) 
population are possibly also limited in their distribution by that of the algae in which they dwell (cf. Russell, I936, p. 6).

Owing to the limited time available, seasonal variations in distribution on the buoys could not be investigated, but the Tees Survey Report (Alexander, etc., I935) states that "apart from the normal seasonal changes which occur in the abundance of various organisms, such as the dying away of hydroids in winter and the seasonal maxima of insect larvae, no seasonal changes were observed in the fauna and flora of the (Tees) estuary".

My thanks are due to the authorities of H.M. Dockyard, Devonport, for facilities afforded for the examination of the buoys; and also to the staff of Plymouth Laboratory, especially to Dr L. H. N. Cooper.

\section{SUMMARY}

Buoys differ from the intertidal area in that they are constantly immersed near the surface of the water and the slope and texture of their surface is constant. The horizontal and vertical distribution of the macrofauna and macroflora on a series of buoys stretching from the open sea up the Tamar estuary is given.

There are differences in estuarine penetration even among species belonging to the same genus. Distribution is likely to be affected by the time of laying the buoys and the period in the water. But the six buoys farthest from the sea were laid down and lifted at approximately the same time. For these, at least thirty species were available for colonization, but little more than half that number was found even on the most seaward; and the number decreased up-river.

Although there is more suspended silt in the estuary than in the sea and although this increases up-river, the penetration of suspension and nonsuspension feeders is similar.

Generally organisms become less numerous and smaller towards the upriver end of their range. Where there is a tendency to lesser density (not size) in a species towards the seaward end of the range, this is largely due to competition for space. Those organisms which do penetrate the estuary have some (new species come in) of the space normally shared with those which do not. Density also decreases where one animal gives way with overlapping to another of similar habits. There is usually no overlapping and no density decrease where replacement occurs in plants.

Dominants on these buoys are filamentous green algae, Ulva, Enteromorpha, Polysiphonia, Mytilus and Amphipoda. Mytilus competes with the algae.

Salinity seems clearly to be the main limiting factor. Range of fluctuation alone may be less important than range plus rate of fluctuation. Average salinity decreases and range and rate of fluctuation increases in the up-river direction. Salinity data, however, do not suffice to explain all the observed 
facts of distribution so that other chemical and physical factors must be taken into account in association with salinity. Organisms such as amphipods and algae, which cannot close up to await the return of suitable conditions like Mytilus, sometimes withstand I2\% fluctuations ( 9 atm. of osmotic pressure) four times in $24 \mathrm{hr}$. at springs in winter.

Data are given which show the observed salinity-fluctuation-tolerance of certain organisms in the Tamar. After an exceptionally rainy winter, certain organisms on buoys withdrew their limits a little down-river. On the shore, though some had retreated, others maintained their position, while one had actually advanced from the position it occupied after a dry summer some years previously. With two exceptions all these could close down like Mytilus, though whether they could escape the bad conditions like the latter, is not known, for one, Balanus balanoides, had retreated.

Comparisons are made with other work in the Tamar. Differences in numerical order and extent of penetration on shore and buoys indicate that the salinity factor is conditioned by other factors which differ in the two habitats. The fact that organisms penetrate farther up-river on the shore arises largely from the greater and more protracted salinity fluctuation on the buoys compared with an equivalent point on the shore or bottom.

The vertical algal zonation normal to the shore is much compressed on the buoys. This is due mainly to light penetration and to a lesser extent to constant immersion. Light penetration decreases up-river and the zonal boundaries exhibit a corresponding approach to the surface in the up-river direction; this is shown to be mainly, if not entirely, governed by the daylight factor. Spectral composition also changes up-river but that the composition of the flora changes likewise may be due partly to salinity and temperature gradients.

\section{REFERENCES}

Alexander, W. B., Southgate, B. A., and Bassindale, R., I935. Survey of the River Tees. Part II. The Estuary-chemical and biological. D.S.I.R. Water Pollution Research, Tech. Paper No. 5, H.M. Stationery Office.

Atkins, W. R. G., I9i6. Some Recent Researches in Plant Physiology. London, I9I6.

BAKER, S. M., I9IO. On the causes of zoning of brown seaweeds on the seashore. II. New Phytologist, Vol. Ix, pp. 54-7.

BøRGESEN, F., I908. The algal-vegetation of the Faroese coasts with remarks on the phyto-geography. Botany of the Faroes, Part III, pp. 683-834.

Colman, J. S., I933. The nature of the intertidal zonation of plants and animals. Fourn. Mar. Biol. Assoc., Vol. xviII, pp. 435-76.

Cooper, L. H. N. \& Milne, A., I938. The ecology of the Tamar estuary. II. Underwater illumination. Fourn. Mar. Biol. Assoc., Vol. xxir, pp. 509-28.

—_ I939. The ecology of the Tamar estuary. V. Under-water illumination. Revision of data for red light. Fourn. Mar. Biol. Assoc. Vol. xxiII, pp. 39I-96.

Crawford, G. I., I937. The fauna of certain estuaries in West England and South Wales with special reference to the Tanaidacea, Isopoda and Amphipoda. Fourn. Mar. Biol. Assoc., Vol. xxI, pp. 647-62.

Elton, C., I927. Animal Ecology. New edition, 1935. London: Sidgwick and Jackson. 
A. MILNE

FISCHER, E., I928. Recherches de bionomie et d'océanographie littorales sur la Rance et le littorale de la Manche. Ann. Inst. Océanogr. Paris. Tome I, v, fasc. 3, pp. 20 I-429.

FischeR-PIETTE, E., I93I. Sur la pénétration des diverses espèces marines sessiles dans les estuaires et sa limitation par l'eau douce. Ann. Inst. Océanogr. Tome x, fasc. 8. pp. $217-43$.

FISCHER-PIETTE, E., I933. Nouvelles observations sur l'ordre d'euryhalinité des espèces littorales. Bull. Inst. Océanogr., No. 6r9, pp. I-I6.

- 1934. Faune et flore de Saint-Servain en 1934. Bull. Lab. Saint-Servain., fasc. 13 , pp. 22-30.

— I935. Histoire d'une moulière. Observations sur une phase de déséquilibre faunique. Bull. Biol. Fr. Belg., Tome LxIx, fasc. 2, pp. I53-77.

Flattely, F. W. \& Walton, C. L., 1922. The Biology of the Seashore. London: Sidgwick and Jackson.

FRASER, J. H., I938. The fauna of fixed and floating structures in the Mersey estuary and Liverpool Bay. Proc. Trans. L'pool Biol. Soc. Vol. LI, pp. I-2I.

Hamel, G., I923. Sur la limite de la végétation dans la Manche d'après les dragages effectués par le "Pourquoi-Pas?" C.R. Acad. Sci. Paris, Tome 176, pp. 1568-70.

Hartley, P. H. T. \& Spooner, G. M., 1938. The ecology of the Tamar estuary. I. Introduction. Fourn. Mar. Biol. Assoc., Vol. xxII, pp. 50I-508.

Huntsman, A. G., I9I8. The vertical distribution of certain intertidal animals. Trans. Roy. Soc. Canada, Sect. Iv, p. 53.

Marine Biological Association. I93I. Plymouth Marine Fauna. 2nd edition.

MILnE, A., I938. The ecology of the Tamar estuary. III. Salinity and temperature conditions in the lower estuary. Fourn. Mar. Biol. Assoc., Vol. xxII, pp. 529-42.

Newton, L., I931. A Handbook of the British Seaweeds. British Museum, London.

Orton, J. H., I929. Observations on Patella vulgata. Part III. Habitat and habits. fourn. Mar. Biol. Assoc., Vol. xvi, pp. 277-88.

- - 1930. Growth-inhibitive value of paints. Fourn. Mar. Biol. Assoc., Vol. XvI, pp. $373-452$.

Percival, E., I929. A report on the fauna of the estuaries of the River Tamar and the River Lynher. Fourn. Mar. Biol. Assoc., Vol. xvI, pp. 8I-I08.

Russell, F. S., 1936. Submarine illumination in relation to animal life. Rapp. Proc. Verb. Cons. Int. Expl. Mer., vol. CI, 2ème Partie, pp. I-8.

SERventy, D. L., I935. Observations on Gammarus zaddachi Sexton, an estuarine amphipod. Rev. Hydrob. Hydrog. Bd xxxII.

\section{Appendix I. Dates of Laying and Examination of Buoys}

$\begin{array}{lll}\text { Name of buoy } & \text { Laid down } & \text { Examined } \\ \text { Mewstone } & \text { Jan. I936 } & \text { Feb. II I937 } \\ \text { New Rock } & \text { Jan. I936 } & \text { May } 4 \text { I937 } \\ \text { Panther } & \text { Jan. I936 } & \text { May } 3 \text { I937 } \\ \text { Mallard } & \text { Apr. I936 } & \text { Apr. 23 I937 } \\ \text { D 4 } & \text { Apr. I936 } & \text { June IO I937 } \\ \text { H I } & \text { Dec. I935 } & \text { Feb. } 5 \text { I937 } \\ \text { H 4 } & \text { Dec. I935 } & \text { Feb. I6 I937 } \\ \text { H } 7 & \text { Dec. I935 } & \text { Feb. 22 I937 } \\ \text { H II } & \text { Dec. I935 } & \text { Feb. I7 I937 } \\ \text { H I5 } & \text { Nov. I935 } & \text { Feb. IO I937 } \\ \text { Neal Point } & \text { Dec. I935 } & \text { Mar. 9 I937 }\end{array}$




\section{APPENDIX II. Notes ON IDENTIFICATION}

The species are as in the Plymouth Marine Fauna (193I), and A Handbook of the British Seaweeds (Newton, I93I). In some cases it was impossible to give more than the generic name either because the specimen was in a bad state of preservation (especially the smaller coelenterates) or the systematics are confusing (e.g. Molgula and Halichondria - of the latter, L. R. Crawshay of the Plymouth Laboratory holds that there may be several species at Plymouth all formerly called $H$. panicea). I am indebted to the following for aid in identification:

E. W. Sexton, G. I. Crawford and G. M. Spooner-certain Crustacea.

L. R. Crawshay-certain sponges.

H. B. Moore-Balanids.

D. P. Wilson-certain worms.

Professor Stephenson-Metridium sp.

W. J. Rees-small coelenterates.

Professor Lily Newton-certain algae.

Professor Theinemann-insect larvae. 